\title{
DIFFERENCE OF LIQUID SEMEN QUALITY ONGOLE CROSSBRED USING DIFFERENT EXTENDERS STORED IN ICE FILLED THERMOS
}

\author{
Sulistyowati Deny*, Graduate Student \\ Faculty of Animal Husbandry, University of Brawijaya, Malang, Indonesia \\ Yekti Aulia Puspita Anugra, Wahjuningsih Sri, Susilawati Trinil \\ Department of Animal Production, Faculty of Animal Husbandry, University of Brawijaya, \\ Malang, Indonesia \\ *E-mail: denz.dvm99@gmail.com
}

\begin{abstract}
The purpose of this study was to know the difference of liquid semen quality Ongole crossbred in CEP-3 (Bovine Serum Albumin (BSA) in CEP-2 substituted with 0,4\% albumen) and tris aminomethane yolks without raffinose which stored in thermos contained with ice cubes. Research was conducted at Sumber Sekar Laboratory Animal Husbandry Faculty of Brawijaya University. The variables observed were motility, sperm membrane integrity and total motile sperm. Data were analyzed using unpaired design $\mathrm{T}$ test, total motile sperm tested using Pearson's Chi Square with expectation value of 40 million motile sperm $/ \mathrm{ml}$ sperm. The results showed that the extenders treatment of P1 and P2 did not give significant difference $(p>0,05)$ to sperm motility, but gave significant difference $(p<0,05)$ on the $4^{\text {th }}$ and $6^{\text {th }}$ hours preservation to sperm membrane integrity of Ongole crossbred stored in ice filled thermos. The conclusion of the research was CEP-3 and tris aminomethan yolks without raffinose have the same ability to maintenance quality of Ongole crossbred's liquid semen stored in ice filled thermos.
\end{abstract}

\section{KEY WORDS}

Liquid semen, ongole crossbred, extender, membrane integrity.

Artificial Insemination (Al) technology that is commonly done in Indonesia using frozen semen. The problem of frozen semen used in rural areas were the lack of liquid nitrogen availability. The alternative solution for this were using liquid semen. Liquid semen needs an extender which capable of retain the semen quality and also gives a good nutrition for the sperm during the preservation and cryopreservation (Devita et al., 2014; Firdausi et al., 2014). An extender needs to be made from available and affordable ingredients (Susilawati, 2011).

CEP-3 (Cauda Epididymal Plasma -3) is an extender made from modified CEP-2 research result from Sholikah et al., (2016) by using a $0.4 \%$ egg albumin to substitute Bovine Serum Albumin (BSA) and added with $10 \%$ egg yolk. The extender can retain the Ongole crossbred semen quality which stored in $3-5^{\circ} \mathrm{C}$ until day 6 . Other extender used is tris aminomethane research result from Ratnawati et al., (2017) showed that in the tris aminomethane without raffinose extender able to retain the motility and progressive motility of Madura bull sperm during 5 days of cold storage.

Al practice in the field needs to be carried by medium from the storage to Al acceptor. The medium is expected to be able to retain the liquid semen quality. The available medium for inseminator is a thermos. The storage temperature that could retain the liquid semen quality is a low temperature (Soeparna and Arifiantini, 2013) hence in this research, ice is used to keep the temperature low for longer period.

In accordance to the explanation above, the research is using CEP-3 added with $10 \%$ yolk and tris aminomethane without raffinose added with $20 \%$ yolk as extenders which are kept in thermos filled with ice to determine which extender is better to be applied on Ongole crossbred liquid semen. 


\section{MATERIALS AND METHODS OF RESEARCH}

The research is conducted from August until November 2017 in Sumber Sekar laboratory of Animal Husbandry Faculty of Brawijaya University, Malang. The material for the research is fresh semen from 2 year old Ongole crossbred with body weight $237 \mathrm{~kg}$. The fresh semen used in the research have ++ mass motility and $50-60 \%$ individual motility. The yolk and albumin used in the research comes from layer hen (egg is 3 days old or less).

The method used is laboratory experiment with 2 treatment and 5 repetition. The treatments are: semen is diluted with extenders P1: CEP- $3+10 \%$ egg yolk and P2: tris aminomethane without raffinose $+20 \%$ egg yolk. Liquid semen is stored in ice filled thermos with initial temperature $0^{\circ} \mathrm{C}$. Observation is done after the storage at 0 hour until $8^{\text {th }}$ hour.

Before the collection, the Ongole crossbred is fed and cleaned on it's preputium. Semen from the Ongole crossbred is collected twice a week using an artificial vagina. Semen is collected in the morning. The collected semen would be tested macroscopically and microscopically. Macroscopic test including volume, color, consistency and $\mathrm{pH}$ test. Microscopic test including concentration, mass motility, individual motility and sperm membrane integrity.

Preparation CEP-3 diluent. Measuring ingredient $0.88 \mathrm{~g} \mathrm{NaCl}$ (Merck; pro analysi); 0.52 g KCl (Merck; EMSURE); $0.44 \mathrm{~g} \mathrm{CaCl}_{2} 2\left(\mathrm{H}_{2} \mathrm{O}\right)$ (Merck; pro analysi); $0.81 \mathrm{~g} \mathrm{MgCl}_{2} .6\left(\mathrm{H}_{2} \mathrm{O}\right)$ (Merck; pro analysi); $1 \mathrm{~g} \mathrm{NaHCO}_{3}$ (Merck; pro analysi); $1.10 \mathrm{~g} \mathrm{NaH}_{2} \mathrm{PO}_{4}$ (Merck; EMSURE); $2.72 \mathrm{~g} \mathrm{KH}_{2} \mathrm{PO}_{4}$ (Merck; pro analysi); $2.72 \mathrm{~g}$ fructose (Merck; Darmstadt Germany); $1 \mathrm{~g}$ sorbitol; 8.2 citric acid (Merck; EMSURE); $16.19 \mathrm{~g}$ tris (Vivantis Inc. USA), dan $0.05 \mathrm{~g}$ gentamycin. The ingredients then added to an erlenmeyer flask and also added $1 \mathrm{lt}$ of deionized water (DI), homogenized with a stirrer for 30 minutes, $\mathrm{pH}$ is kept at 6.6 with $\mathrm{NaOH}$ as buffer, $0.4 \%$ albumen and $10 \%$ egg yolk is added when the mixture is used as diluents (Sholikah et al., 2016).

Preparation Tris Aminomethan without Raffinose. Ingredients are $13.63 \mathrm{~g}$ tris aminomethane (Merck; pro analysi); $7.62 \mathrm{~g}$ citric acid (Merck; EMSURE); $15 \mathrm{~g}$ lactose (Merck KGaA Darmstadt, Germany) and $5 \mathrm{~g}$ fructose (Merck Darmstadt, Germany), mixed in erlenmeyer flask, added with $800 \mathrm{ml}$ aquadest and homogenized with a stirrer for 10-15 minutes. The temperature is lowered to $37^{\circ} \mathrm{C}$ then added $1 \mathrm{~g}$ of penicillin and $1 \mathrm{~g}$ of streptomycin homogenized again for 10-15 minutes. $20 \%$ egg yolk is added when the mixture is used as diluents (Susilawati, 2013).

The observed variables in this research is the quality of the sperm of the diluted semen, including:

- Individual motility is the progressive movement of the sperm. A drop of semen is taken and put on on an object glass and covered with cover glass then observed with light microscope at 400x magnification (Susilawati, 2013; Ax et al., 2008).

- Sperm membrane integrity is measured with Hypoosmotic Swelling (HOS) test by adding $0,1 \mathrm{ml}$ semen in $1 \mathrm{ml}$ of HOS solution $(7.34 \mathrm{~g}$ natrium citric and $13.52 \mathrm{~g}$ fructose in $1000 \mathrm{ml}$ aquadest) incubated in $37^{\circ} \mathrm{C}$ for 30 minutes then observed with light microscope at 400x magnification (Susilawati, 2013).

- Total motile sperm. Counting of motile sperm by multiplying semen volume with sperm concentration and progressive motile sperm percentage (Susilawati, 2013).

Data from the research is analyzed with unpaired design $T$ test. In the storage period reacing $40 \%$ motility and total motile sperm are tested with Pearson's Chi Square with expectation value of 40 million motile sperm $/ \mathrm{ml}$.

\section{RESULTS AND DISCUSSION}

Ongole crossbred semen quality. Average Ongole crossbred semen quality which are used in this research is presented in Table 1.

The evaluation showed that the average volume of Ongole crossbred semen used in this research is $2.26 \pm 0.7 \mathrm{ml}$ which is lower than Sholikah et al., (2016) which is $5.9 \pm 1.9 \mathrm{ml}$. Semen volume still can be categorized as normal according to Garner and Hafez (2008), bull 
semen volume is varied around $1-15 \mathrm{ml}$ or $5-8 \mathrm{ml}$ per ejaculation. Color of semen is yellowish white which is normal according to Susilawati (2013) who stated that bull semen color normally yellowish white or milk white caused by riboflavin content. Average $\mathrm{pH}$ is 7 which is normal in accordance with Garner and Hafez (2008) who stated that bull semen pH is around 5.4 to 7.8. Consistency is moderate with sperm concentration $1176.00 \pm 146.56 \times 10^{6}$ sperm $/ \mathrm{ml}$. The result is in accordance with Susilawati (2013) who stated that semen consistency is consistent with sperm concentration. Semen consistency is considered moderate if the concentration contains $1000 \times 10^{6}-1500 \times 10^{6} \mathrm{sperm} / \mathrm{ml}$ semen.

Table 1 - Average Ongole Crossbred Semen Evaluation

\begin{tabular}{|l|l|}
\hline \hline Variable & Average \\
\hline Volume $(\mathrm{ml})$ & $2.26 \pm 0.70$ \\
\hline Color & Yellowish \\
\hline Consistency & Moderate \\
\hline $\mathrm{pH}$ & $7.00 \pm 0.00$ \\
\hline Concentration $\left(10^{6} / \mathrm{ml}\right)$ & $1176.00 \pm 146.56$ \\
\hline Mass motility & ++ \\
\hline Individual motility $(\%)$ & $56.00 \pm 2.24$ \\
\hline Membrane integrity $(\%)$ & $53.71 \pm 6.16$ \\
\hline
\end{tabular}

Microscopical test result showed mass motility ++ and individual motility with average $56.00+2.24 \%$. Fresh semen with mass motility ++ or more can be used in Al practices (Shukla, 2011). Individual motility still can be considered as normal according to Susilawati (2011) who stated that motility of fresh bull around $70-90 \%$. Percentage of membrane integrity of fresh semen is $53.71 \pm 6.16$ which is lower than Costa et al., (2016) result which is $75.52 \pm 12.66 \%$.

Sperm Motility during The Cold Storage in Ice Filled Thermos. Ongole crossbred liquid semen is stored with the medium inside the ice filled thermos with $0^{\circ} \mathrm{C}$ temperature. Sperm individual motility is observed every hour until the $8^{\text {th }}$ one. Average percentage of sperm progressive motility is presented in Table 2.

Tabel 2 - Average Percentage of Sperm Motility

\begin{tabular}{ll|l}
\hline \multirow{2}{*}{ Storage time (hour) } & \multicolumn{2}{l}{ Sperm Motility (\%) } \\
\cline { 2 - 3 } & $\mathrm{P} 1$ & $\mathrm{P} 2$ \\
\hline 0 & $41.00 \pm 2.24$ & $42.00 \pm 2.74$ \\
1 & $38.00 \pm 2.74$ & $40.00 \pm 5.00$ \\
2 & $35.00 \pm 5.00$ & $38.00 \pm 2.74$ \\
3 & $34.00 \pm 4.18$ & $37.00 \pm 2.74$ \\
4 & $34.00 \pm 4.18$ & $36.00 \pm 2.24$ \\
5 & $30.00 \pm 7.07$ & $29.00 \pm 6.52$ \\
6 & $26.00 \pm 6.52$ & $27.00 \pm 7.58$ \\
7 & $24.00 \pm 5.48$ & $23.00 \pm 9.75$ \\
8 & $20.00 \pm 10.00$ & $22.00 \pm 9.75$ \\
\hline
\end{tabular}

P1: CEP-3 + 10\% egg yolks;

$P 2$ : Tris aminomethane without raffinose $+20 \%$ egg yolk.

According to Table 2, the average percentage of sperm motility of PO bull in the research showed a decline the longer it stored in the storage whether it is in P1 medium or P2 medium. This is in accordance with Agustian et al., (2014) who stated that the longer the semen is stored in cold temperature will cause the decline in sperm potency and progressive motility. The decline of individual motility during the cold storage is expected to be caused by the decline of used energy. Lukman et al., (2014) stated that decline in motility percentage of sperm during the storage is caused because the source of energy used by sperm is glyserylphosphorylcholine, fructose and sorbitol content in the semen.

Unpaired design T test Data analysis showed that the storage from 0 until 8 hour don't show any significant difference between $\mathrm{P} 1$ or $\mathrm{P} 2$ on sperm motility despite the percentage in $\mathrm{P} 2$ is higher than $\mathrm{P} 1$. This is probably because both of the extenders still have the same 
capability on protecting the sperm. The ingredients of the extenders and addition of egg yolk could protect the sperm from cold shock.

Sperm Membrane Integrity during Stored in Ice Filled Thermos. Plasma membrane integrity is needed to retain the sperm viability (Shukla, 2011). HOS test is an easier method to know the functional integrity of the sperm membrane. The principle of the method is by exposing the sperm in a solution with low osmotic pressure (Rizal and Herdis, 2008). According to Zubair et al., (2013) an intact sperm plasma membrane have positive correlation with motility and abnormality hence the test could be used to determine the semen quality.

Table 3 - Average Percentage of Sperm Membrane Integrity

\begin{tabular}{ll|l}
\hline \multirow{2}{*}{ Storage time (hour) } & \multicolumn{2}{l}{ Sperm Membrane Integrity (\%) } \\
\cline { 2 - 3 } & P1 & P2 \\
\hline 0 & $44.62 \pm 11.79$ & $50.58 \pm 2.76$ \\
1 & $40.25 \pm 10.65$ & $43.61 \pm 7.19$ \\
2 & $31.41 \pm 13.00$ & $44.05 \pm 9.02$ \\
3 & $42.96 \pm 20.91$ & $39.80 \pm 8.29$ \\
$4^{*}$ & $27.52 \pm 9.75^{\mathrm{a}}$ & $49.43 \pm 14.70^{\mathrm{b}}$ \\
5 & $38.75 \pm 12.62$ & $46.73 \pm 8.31$ \\
$6^{*}$ & $23.06 \pm 15.45^{\mathrm{a}}$ & $52.87 \pm 7.71^{\mathrm{b}}$ \\
7 & $25.66 \pm 14.46$ & $44.05 \pm 17.42$ \\
8 & $28.90 \pm 12.88$ & $40.78 \pm 13.35$ \\
\hline
\end{tabular}

$P 1:$ CEP-3 + 10\% egg yolks;

$P 2$ : Tris aminomethane without raffinose $+20 \%$ egg yolk;

*) Different superscript in rows shows significant difference $(P<0.05)$.

Table 3 showed the percentage of sperm membrane integrity stored in ice filled thermos have a tendency to decline. The percentage is lower than Costa et al., (2016) because the average membrane integrity of the fresh semen is lower $53.71 \pm 6.16 \%$.

The unpaired $T$ test result showed that there's a significant difference on storage time $4^{\text {th }}$ and $6^{\text {th }}$ hour which showed that P2 gives a better membrane integrity than P1 but doesn't show significant difference on other storage time. The difference is expected to be caused by the existence of lactose in P2 extender which used as energy source and also a reducting substance and have a more stable structure which minimaze the lipid peroxidation. Lipid peroxidation could cause the plasma membrane damage which would cause death (Rizal and Herdis, 2005). The addition of egg yolk on both extenders acted as the extracellular cryoproctectant substance. Egg yolk contain lipoprotein and lecithin which purpose is to protect the sperm plasma membrane (Yulnawati and Setiadi, 2005; Susilawati. 2011).

Total Motil Sperm. The success on Al procedure is also determined by total motilility and morphology of sperm (Nikbakht and Saharkhiz, 2011). The average of total motile sperm of P1 and P2 which stored in ice filled thermos is presented in Table 4.

Table 4 - Average Total Motil Sperm

\begin{tabular}{ll|l}
\hline Treatment & \multicolumn{2}{l}{ Total Motil Sperm (million/ml) } \\
\cline { 2 - 3 } & $4^{\text {th }}$ hour & $5^{\text {th }}$ hour \\
\hline P1 & $34.00 \pm 4.18$ & $30.00 \pm 7.07^{*}$ \\
P2 & $36.00 \pm 2.24$ & $29.00 \pm 6.52^{*}$ \\
\hline Expectation value of 40 million motile sperm $/ \mathrm{ml}$ &
\end{tabular}

P1: CEP-3 $+10 \%$ egg yolk

P2: Tris sminomethane without raffinose $+20 \%$ egg yolk

*) significant difference $(P<0.01)$

Analysis with Pearson's Chi Square on storage time on $4^{\text {th }}$ and $5^{\text {th }}$ hour with expectation value of 40 million motile sperm per 100 million concentration showed no significant difference $(P>0.05)$ on $4^{\text {th }}$ hour, but showed a significant difference $(P<0.01)$ on $5^{\text {th }}$ hour. This means that liquid semen on extenders P1 and P2 still can be applied for Al until $4^{\text {th }}$ hour because the total motile sperm doesn't show significant difference with expectation 
value of 40 million motile sperm $/ \mathrm{ml}$, while the ones stored until the $5^{\text {th }}$ hour no longer able to be applied on Al because the significant diference with expectation value of 40 million motile sperm $/ \mathrm{ml}$.

\section{CONCLUSION AND SUGGESTIONS}

According to the research, it can be concluded that CEP- $3+10 \%$ egg yolk extender (P1) have the same capability with tris aminomethane without raffinose $+20 \%$ egg yolk (P2) in retaining the motility of Ongole crossbred sperm stored in ice filled thermos as medium, but the P2 could gives a better sperm membrane integrity during the $4^{\text {th }}$ and $6^{\text {th }}$ hour of storage than P1.

Suggestion from the research that need to do further research using semen with individual motility $\geq 70 \%$.

\section{REFERENCES}

1. Amaliya, A., S. Utama and Hardijanto. (2017). Post Thawing Quality, Expression HSP 70 and Sperm DNA damage on Limousin Bull after Cooling on $5^{\circ} \mathrm{C}$ Temperature. Veterina Medika. 10 (1): 77-86

2. Agustian, M., M.N. Ihsan, and N. Isnaini. 2014. The Effect of Semen Storage Time with Tris Aminomethane Egg Yolk at Room Temperature on The Quality of Sperm Boer goat. J. Ternak Tropika. 15(2): 1-6.

3. Ax, R. L., M.R. Dally, B.A. Didion, R.W. Lenz, C.C. Love, D.D. Varner, B. Hafez, and M.E. Bellin. (2008). Artificial Insemination dalam Reproduction in Farm Animals. $7^{\text {th }}$ edition. Edited by Hafez E. S. E. Lippincott Williams \& Wilkins. Maryland. USA: 376-389.

4. Costa, N., T. Susilawati, N. Isnaini, dan M. Ihsan. (2016). Effect of Different Dilution Materials Usage on Indonesian Peranakan Ongole Bull Sperm Quality During Cooling Process. Indo American Journal of Pharmaceutical Sciences 3 (4): 379-385.

5. Devita, V.B., T. Susilawati, and S. Wahyuningsih. (2014). Quality of Limousin Bull Semen with Different Diluents during Cooling Period. J. Ternak Tropika 15 (1): 13-20.

6. Firdausi, P.A., T. Susilawati, and S. Wahyuningsih. (2014). Quality of Limousin Bull Semen during Cooling Period with CEP-2 Diluent and Addition of Various Concentration of Coconut Milk. J. Ternak Tropika 15 (1): 21-30.

7. Garner, DL and E.S.E. Hafez. (2008). Spermatozoa and Seminal Plasma In: B. Hafez and E.S.E Hafez (ed). Reproduction in Farm Animals. $7^{\text {th }}$ edition. Lippincott Wiliams. Philadelphia. ISBN 0-683-30577-8. 96-110.

8. Lukman, H.Y., W. Busono, S. Wahyuningsih, and S. Suyadi. (2014). Sperm Motility and Viability after a-Tocopherol Dilution in Tris Aminomethane-Base Extender During Cold Storage in Bali Bull. International Journal of ChemTech Research 6 (14): 5726-5732.

9. Nikbakht, R., and N. Saharkhiz. (2011). Influence of Sperm Morphology, Total Motile Sperm Count of Semen and Number of Motile Sperm Inseminated in Sperm Samples on the Success of Intrauterine Insemination. International Journal of Fertility and Sterility 5 (3): 168-173.

10. Ratnawati, D., N. Isnaini and T. Susilawati. (2017). The use of CASA on Observing The Motility of Madura Bull Sperm. JIIP 27 (1): 80-95.

11. Rizal, M., and Herdis. 2005. Survivability of Garut Ram Epididymis Sperm Cryopreservation with Modified Tris Diluent. Hayati. 12 (2): 61-66.

12. 2008. Artificial Insemination on Sheep. Rineka Cipta Publisher. Jakarta. ISBN: 978-979518-952-7.

13. Sholikah, N., N. Isnaini, A.P.A. Yekti, and T. Susilawati. (2016). The Effect of Exchanging The Bovine Serum Albumin (BSA) with Albumen on CEP-2 Extender on Ongole Crossbred Semen Quality in 3-5 $5^{\circ}$ Storage Temperature. JIIP 26 (1): 7-15.

14. Shukla, M.K. (2011). Applied Veterinary Andrology and Frozen Semen Technology. New India Publishing Agency. India. ISBN: 978-93-80235-64-6. 
15. Soeparna and R.I. Arifiantini. (2013). Reproductive Physiology and Artificial Insemination on Horse. IPB Press. Bogor. ISBN: 978-979-493-583-5.

16. Susilawati, T. (2011). Spermatology. Brawijaya University Press. Malang. SBN: 978-6028960-04-5.

17. (2013). Guide of Artificial Insemination on livestock. Brawijaya University Press. Malang. ISBN: 978-602-203-458-2.

18. Yulnawati and M.A. Setiadi. (2005). Motility and Membrane Integrity on Epididymis Sperm of Cat during the Storage on $4^{\circ} \mathrm{C}$ Temperature. Veterinary Media 21 (3): 100-104.

19. Zubair, M., L.A. Lodhi, E. Ahmad and Ghulam. (2013). Hypo Osmotic Swelling Test as Screening for Evaluation of Semen of Bull. Journal of Entomology and Zoology Studies. 1 (6): 124-128. 